\section{My Journey as an International Doctoral Student in the United States}

\author{
Hoi Yuen Chan \\ Doctoral Student \\ Laramie, Wyoming (USA)
}

This article is about my personal experience in a doctoral program in the United States. After working ten years as a high school teacher in Hong Kong, I decided to quit my high school teaching career and to come back to school for my $\mathrm{PhD}$ - not because I no longer enjoy teaching; in fact I still do, but because I do not enjoy spending most of my time with discipline and classroom management. So, I decided to pursue a doctoral degree so that I can teach college students. "I got admitted to a PhD program in the US." I excitedly said to my wife. She was thrilled to hear the good news. We started obtaining visas and told our three daughters about our forthcoming plan.

Our adventure began when we moved to an unknown place in the US without even knowing a single person there. Although both my wife and I felt good about our decision, the tremendous uncertainties lying ahead of us enveloped us. As our plane landed on an American soil, my journey began as well.

I started to get familiar with the school, the $\mathrm{PhD}$ program, and the faculty members. I contacted my program advisor whom I communicated with through e-mails before we came to the US. My advisor, an assistant professor, and I sat down and discussed my four-year plan for my $\mathrm{PhD}$ program such as the core courses and the alternative ones provided in the program. I thought I was ready to start my program here in the US for four years.

In my first year, I took nine credits in my coursework. One of the courses was titled, "Doctoral Studies" in which I learned about a $\mathrm{PhD}$ path. The professor asked us to form our own $\mathrm{PhD}$ committee of five faculty members as early as we could. Some $\mathrm{PhD}$ candidates told me that I had to make sure that the faculty members I am going to choose for my committee could work well with one another. If not, I would struggle trying to get my committee work together smoothly. With this warning in mind, I approached my advisor and invited her to be my chair and four other professors as committee members. By the end of my first year, I formed my own dissertation committee.

In my second year, I continued to take core classes such as research method courses. Everything seemed quite smooth to me. At my fourth semester, I talked to my chair regarding my comprehensive examination. A comprehensive examination usually contains few questions given by the faculty members in the committee, and the student has to answer the questions either in a written or oral format. She asked me, "Are you ready?" I replied, "I don't know." I just knew that most $\mathrm{PhD}$ students had to pass a comprehensive examination before moving to the next stage. After my response, my chair did not say anything. I had never been taught how to prepare for the comprehensive examination; I had no idea about whether I was ready or not. In January 2010, to my disappointment, I found out that my chair was leaving the school. Two weeks later, one of my committee members also decided to leave the school. I was shocked by the unexpected news. I believed that things did not go well as I planned. However, my chair ensured me that she would help me find a good chair for me, and she would let me take the comprehensive examination before she left the school. With her promise, I took the comprehensive examination in March 2010 and successfully defended it a month later. I thought good at that moment because I overcame one of the hurdles that I had to go through in the program. In June, the same year, I found out that another committee member sadly passed away from cancer. Because of that, I had to reform my committee with three new members. I was somewhat discouraged because all these unexpected instances happened suddenly out of my control.

In my third year, I finally completed reforming my committee with a new chair, and two new faculty members. My new chair was a very experienced and intelligent professor, but he is not specialized in my field. During this year, I finished all the required coursework and started preparing my research prospectus, which is also one of the requirements in my $\mathrm{PhD}$ program. In April, I had a defense for my research prospectus. During the defense, only three of my five committee members attended. The other two said that they could not make it, but they were willing to give suggestions on my research prospectus, but they never did. Again, I passed the defense. I was officially considered a $\mathrm{PhD}$ candidate or "ABD" (All But Dissertation). At the end of my third year, I finished collecting the data for my dissertation and started to analyze the data and to write my dissertation chapters. Although I have five faculty members in my committee, I have been working mainly with my chair; the rest of the committee members merely attended my defenses.

I planned to graduate in my fourth year, so I 


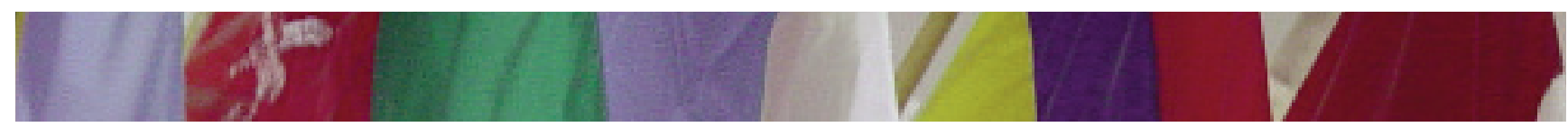

worked hard trying to finish my dissertation and look for a job simultaneously. At the beginning of February, I submitted my result chapter to my chair, but my chair could not respond to my chapter in a timely manner. A month later, I submitted my discussion of the result chapter to him. Then, he realized that he really needed to take some time to look at my chapters. In the first week of March, having looked at my result chapter, my advisor told me that my findings were so thin that I needed to use software to analyze my data again, which meant I could not graduate as planned. I wished he could have mentioned the software long before when I started analyzing my data. After talking with my chair, he decided to ask the school to purchase the software licenses for graduate students to use. Finally, it took a little bit over a month to get the software installed into the computer.

After this instance, I thought that I had all the rights to be upset and to blame others. However, can I put blame on my chair? Should I negotiate with him? Should I complain about it? I do not know and I dare not. I just keep silent to myself. I remember a warning made by a professor in my first semester. He said, "You don't want any surprises." I did not understand what it meant back then, but I do now. Again, I have no control of certain things. However, I realized that everything that has happened on my path could be a typical of $\mathrm{PhD}$ candidates. One of the academic secrets in higher institutions is doctoral education attrition rates (Lovitts, 2001). Doctoral students' voice has seldom been heard because "their points of view are believed to be unimportant or difficult to access by those in power" (McLaughlin \& Tierney, 1993, p. 10). Different challenges and hurdles are there, but there is always a way that we can overcome those challenges.

\section{Suggestions for PhD International Students}

The suggestions below may shed lights on perspective or current $\mathrm{PhD}$ students.

Find the right advisor. Since you are still new in the program and in the school, it takes time for you to get to know the faculty members in your department or even in your college. You may consult with other PhD candidates about whom you should choose to be your advisor because they have been in the department long enough to know who would be an effective mentor for international students. Remember that a knowledgeable and a seasoned professor may not necessarily be a helpful advisor or mentor.

Form your committee with your advisor. After you have selected your advisor, continue to get to know your mentor more. When you start to form your committee, you must discuss honestly with your advisor. The advisor may have a preference whom he or she wants to work with in the committee.

"You are the driver of the bus". You are responsible to drive the bus, not your committee. You should plan with your advisor when you should take the comprehensive examination, when you will defend your dissertation prospectus, and when you plan to graduate and let the rest of your committee members know your timeline.

Meet with your advisor regularly. Everyone is busy. Your mentor has no exception. As you set up a regular meeting with your advisor, you are always in your advisor's schedule. Make use of the time in the meeting. Ask questions or share concerns you may have with your advisor as you are working through your program regardless of what stage you are in.

Attend conferences. Try to attend as many conferences in your field as you can, and present papers in conferences. By doing so, you can build up your network with others in the same field. Also you can keep abreast of the current trends in your specific field.

Expect the unexpected. Prepare yourself emotionally and mentally for some surprises that may occur in your $\mathrm{PhD}$ program. Always have a contingent plan if your odyssey does not go as you plan. Think positively that spending more than four years in the program may not be a terrible thing in the long run.

For some doctoral students, they may have a smooth path in their $\mathrm{PhD}$ program, but for some may not. This article may start an avenue for those like me who are currently in the $\mathrm{PhD}$ program to voice their struggles, discouragement, and eventually the success.

References
Lovitts, B. E. (2001). Leaving the ivory tower: The
causes and consequences of departure from
doctoral study. Lanham, MD: Rowman \&
Littlefield.
McLaughlin, D. \& Tierney, W. G. (1993). Naming
silenced lives: Personal narratives and processes
of educational change. New York, NY: Routledge

\begin{abstract}
About the Author
Hoi Yuen Chan is currently a PhD candidate in Curriculum and Instruction with a specialization in TESOL. His areas of interests include academic writing, freshman composition, and ESL pedagogy. He can be reached at hoiyuen8@hotmail.com
\end{abstract}

